$$
\begin{aligned}
& \text { اثر ضد ميكروبى عصاره آبى سه گَونه مريمَّلى بر باكترىهاى استافيلوكوكوس اورئوس، } \\
& \text { اشرشيا كولى و سودوموناس آئروجينوزا }
\end{aligned}
$$

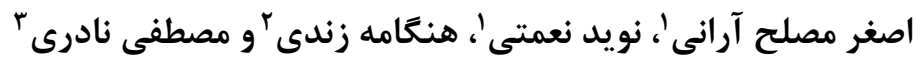

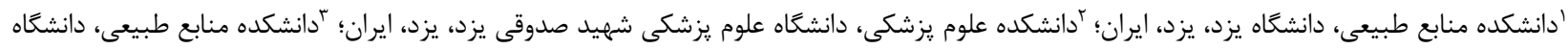

$$
\begin{aligned}
& \text { ايلام، ايلام، ايران } \\
& \text { amosleh@yazd.ac.ir مسئول مكاتبات: اصغر مصلح آرانى ايلام انل }
\end{aligned}
$$

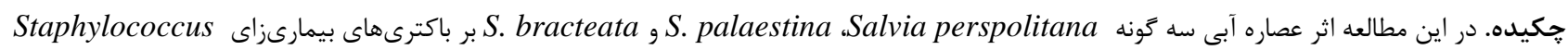
Pseudomonas aeroginosa Escherichia coli aureus

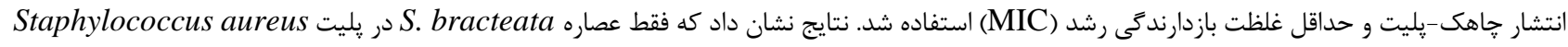

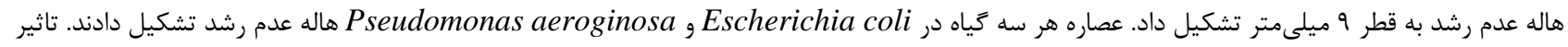

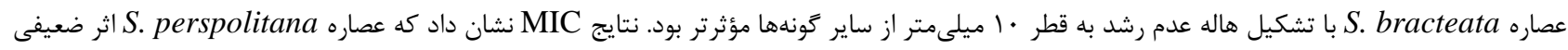

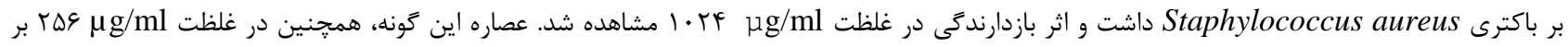

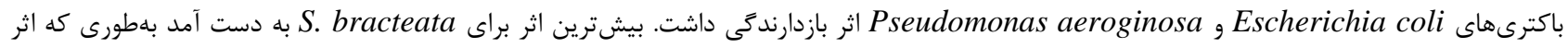

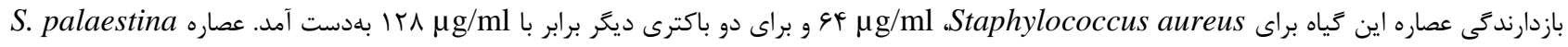

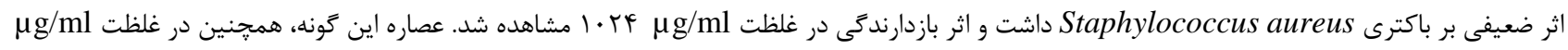

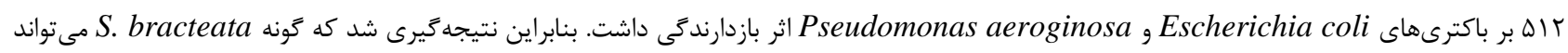

$$
\text { به منزله كونهاى مناسب جهت استفاده ضد باكتريايى تحت مطالعه بيشتر قرار كيرد. }
$$$$
\text { وازههاى كليدى. ايلام، تيره نعنائيان، روش انتشار خاهك، غلظت بازدارندگى، ضد باكترى }
$$

\title{
The antibacterial activity of the water extracts of three species of Salvia on Staphylococcus aureus, Escherichia coli and Pseudomonas aeruginosa
}

\author{
Asghar Mosleh Arany ${ }^{1}$, Navid Nemati ${ }^{1}$, Hengame Zandi ${ }^{2}$ \& Mostafa Naderi $^{3}$ \\ ${ }^{1}$ Natural resources faculty Office, Yazd University, Yazd, Iran; ${ }^{2}$ Faculty of Medical Sciences, Shahid Sadoughi \\ University of Yazd, Yazd, Iran; ${ }^{3}$ Faculty of Natural Resources office, Ilam University, Ilam, Iran \\ Correspondent author: Asghar Mosleh Arany, amosleh@yazd.ac.ir
}

\begin{abstract}
The aim of this study was to evaluate the antibacterial activity of the water extracts of three species of Salvia (S. perspolitana, S. palaestina, S. bracteata) on Staphylococcus aureus, Escherichia coli and Pseudomonas aeroginosa. The antibacterial activity of water extracts of the studied species on the bacterial strains was examined using well diffusion method and minimum inhibitory concentration (MIC). Results showed that only S. bracteata formed growth inhibitory zone $(9 \mathrm{~mm})$ on Staphylococcus aureus. The extracts of all three plants formed growth inhibitory zone on E.coli and $P$. aeroginosa. The extract of $S$. bracteata was more effective than that of the other species. Results for MIC also showed that the extracts of S. perspolitana had the lowest effect on St. aureus and its MIC was observed in a concentration of $1024 \mu \mathrm{g} / \mathrm{ml}$. The extracts of this species had the inhibitory effect in a concentration of $256 \mu \mathrm{g} / \mathrm{ml}$. The uppermost inhibitory effect was provided by the extract of $S$. bracteata, since the minimum inhibitory concentration of
\end{abstract}


this species for $S$. aureus was equal to $64 \mu \mathrm{g} / \mathrm{ml}$; and for the other two bacteria, it was equal to $128 \mu \mathrm{g} / \mathrm{ml}$. The extracts of S. palaestina had the lowest effect on S. aureus and its MIC was observed in a concentration of $1024 \mu \mathrm{g} / \mathrm{ml}$. The extracts of this species had an MIC equal to $512 \mu \mathrm{g} / \mathrm{ml}$ for the other two bacteria. It was concluded that $S$. bracreata could be considered a suitable species with anti-bacterial activities in future researches.

Keywords. antibacteria, Ilam, inhibitory concentration, Lamiaceae, well diffusion method

سيستم ايمنى ناتوان افراد استفاده كرده و در آنها عفونت و سموم مضر براى بافتها ايجاد مى كند. اين باكترى سبب ناتب عفونتهاى مجارى ادرارى، سيستم تنفسى، التهاب و آماس يوست، عفونتهاى باى

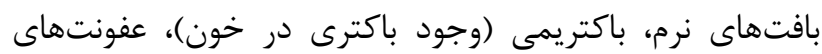

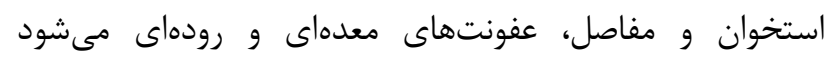

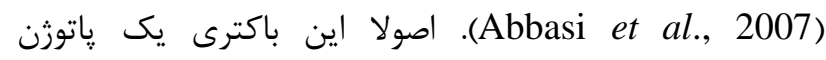
بيمارستانى است. اين اركانيسم بيشتر از راه ميوهها، كياهان و

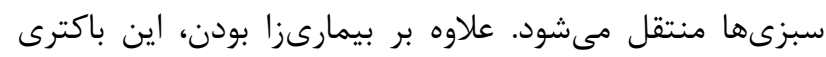

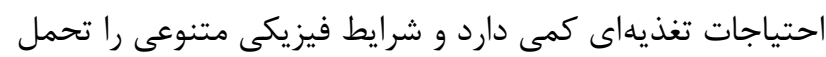
مى كند. همجنين به خوبى براى زندگى و بقاء در محيطهايى بال

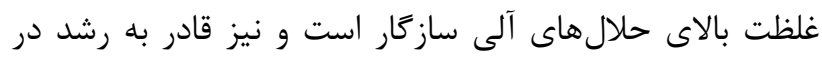

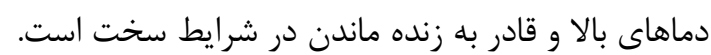

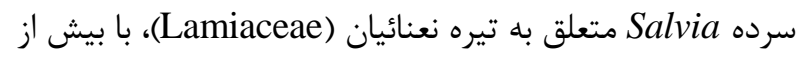

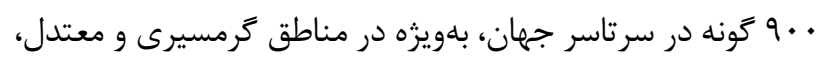

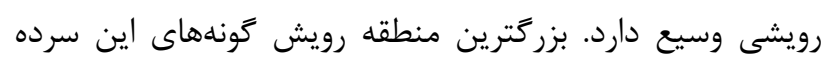
آمريكا و جنوب غربى آسيا است (Walker \& Sytsma, 2007).

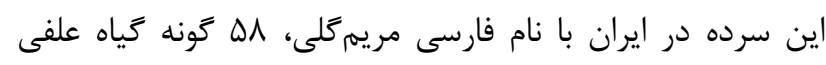

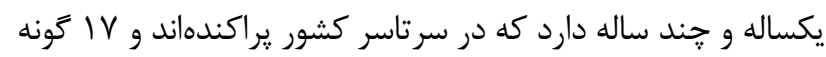
آن انحصارى ايران هستند. بقيه گونهها علاوه بر ايران در ساير مناطق داطق دانق

به خصوص آسيا و آفريقا مىرويند (Mozaffarian, 1996).

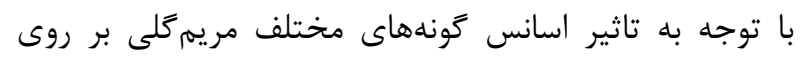
ميكروبها، تحقيق حاضر تأثير عصاره آبى سه گونه مريمثلى Salvia perspolitana Boiss., S. palaestina Benth., S. ) , إ بر باكترىهاى استافيلوكوكوس (bracteata Banks \& Sol. اورئوس، اشرشياكولى و سودوموناس آئروجينوزا مورد بررسى قرار اركيتري مى دهد.

\section{مواد و روشها \\ كياهان تحت مطالعه}

كونه Salvia palaestina گياهى جندساله بوتهاى و يوشيده از كرك است. با ساقههايى به ارتفاع · † تا • م سانتىمتر كه در برخى

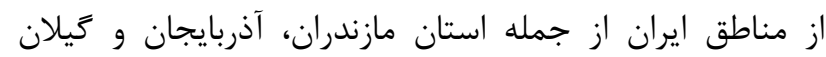
يراكنش دارد (Hedge, 1982). گَونه مريمَّلى يرسيوليسى (Salvia perspolitana) كونهاى انحصارى در استان ايلام است. اين گياه از يراكنش بسيار محدودى يرى
مقلدمه كياهدرمانى در بيمارىها و بهويزه بيمارىهاى عفونى در سال -

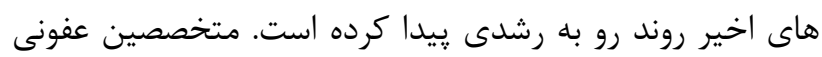

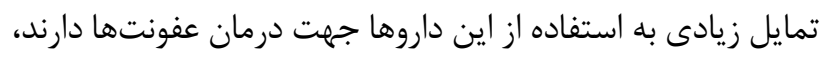
زيرا عوارض اين داروها در مقايسه با داروهاى شيميايى بهطور قابل

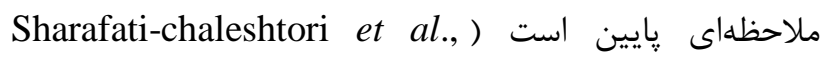

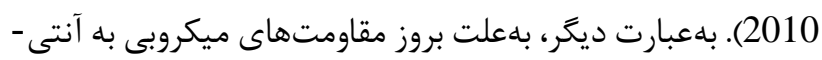

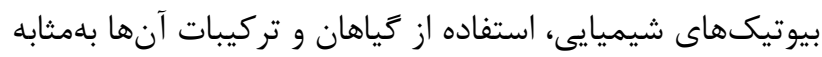
جايگزينى براى آنتىبيوتيكهاى شيميايى مورد توجه قرار گرفته

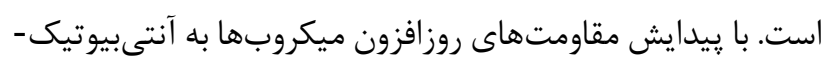
ها، انجام تحقيقات بيشتر در اين زمينه ضرورت دارد ( Pirnia et

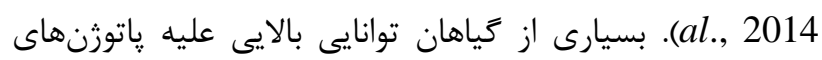

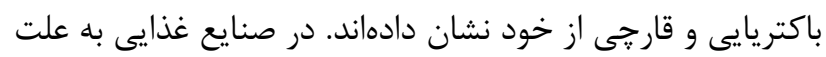
گرايش منفى مردم به مصرف غذاهاى با نتحهدارندهایى شيميايى،

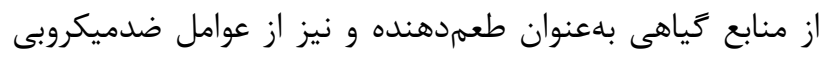

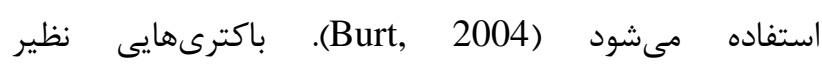
استافيلوكوكوس اورئوس، اشرشياكولى و سودوموناس آئروجينوزا در مسموميتهاى غذايى نقش بسيار مهمى ايفا مى كنند. استافيلوكوكوس اورئوس به دليل توليد رنحدانه كارتنوئيدى به نام

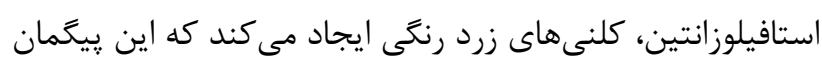

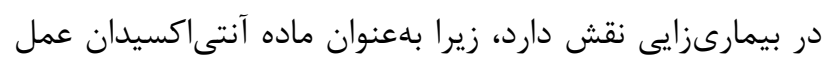
كرده و موجب در امان ماندن باكترى در برابر راديكالهاى دأ آزاد

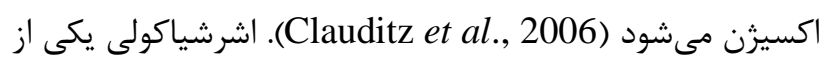
ياتوزنهاى فرصتطلب بيمارستانى و همجنين شايعترين عامل باكتريايى است كه از عفونت انسانى جدا شده است. مقاومت اين باكترى نسبت به داروها در درمان بيماران بسترى در بيمارستانها

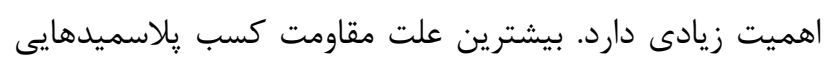

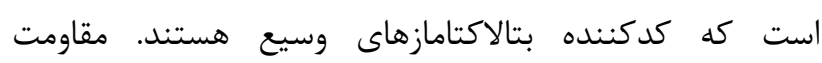
ضدميكروبى در اشرشياكولى در سراسر دنيا ززارش شده است و

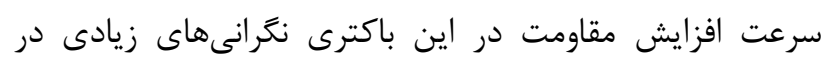
كشورهاى در حال توسعه و توسعه يافته ايجاد كرده است Formisano et al., 2007) كرم منفى است كه بيشتر در ييرامون ما يافت مىشود. اين موجود

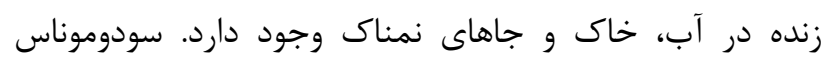
آئروجينوزا يكى بيمارىزاى فرصتطلب است. اين باكترى از 
محيط ترييتيكازسوى آَار (Merck, Darmstadt, Germany) جهت اثبات خلوص باكترىها كشت داده شدند. تهيه سوسيانسيون باكتريايى

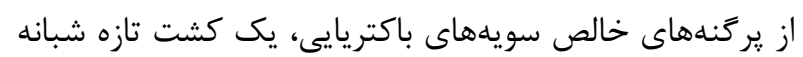

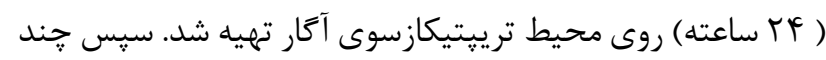

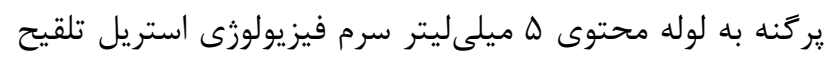

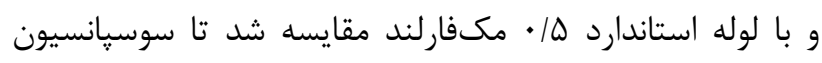

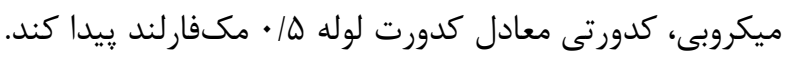

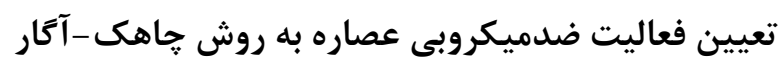
جهت بررسى فعاليت ضد ميكروبى عصاره از روش خاهـ

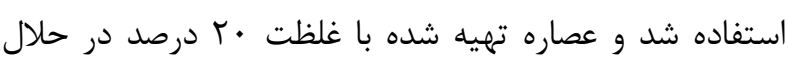
DMSO

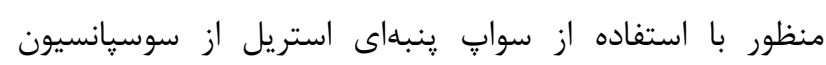

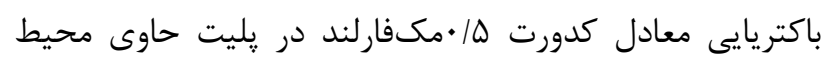

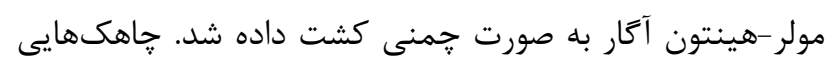

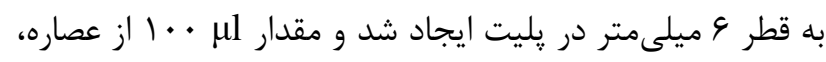

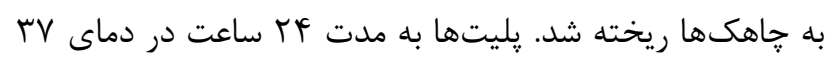

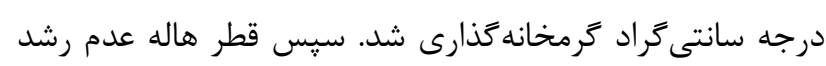

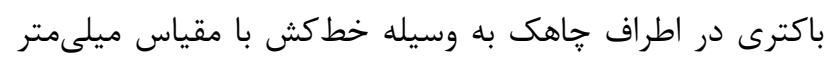

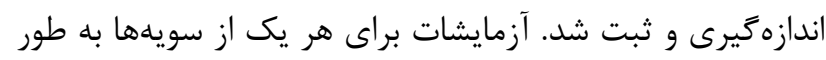

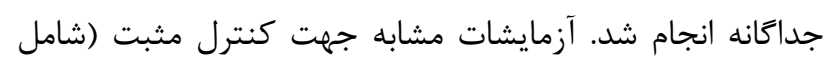

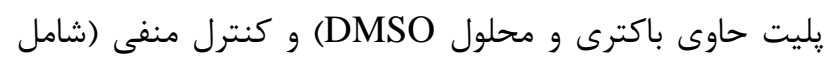

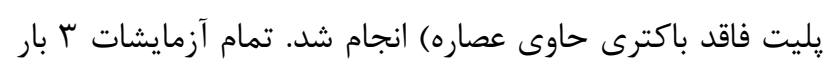
تكرار شد و ميانكَين دادهها تعيين شد (Inouya et al., 2001). سنجش حداقل غلظت بازدارندكى رشد (MIC) با استفاده

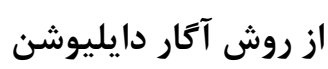

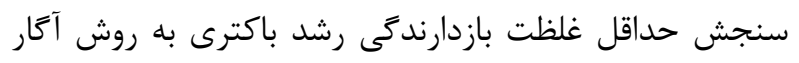

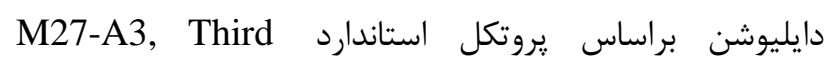
براى عصارههايى كه در روش قبلى CSLI (Edition, 2008)

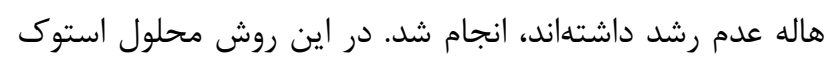

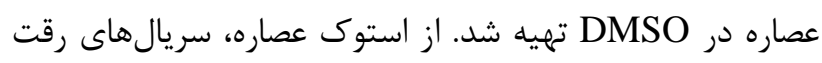

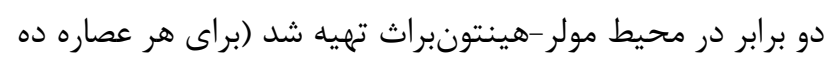

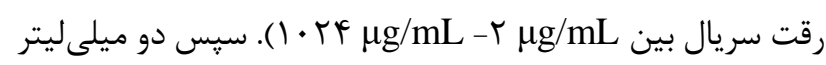

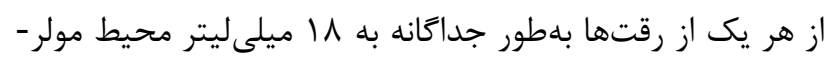

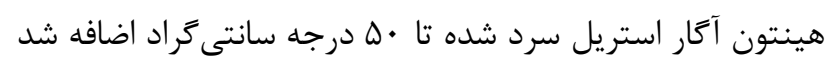

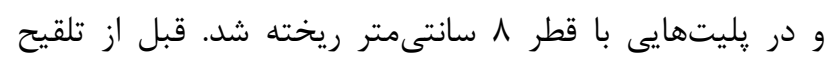

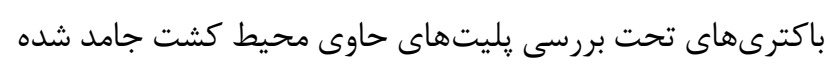

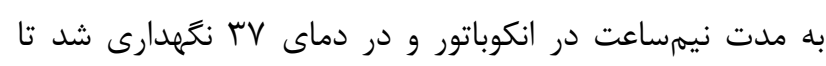

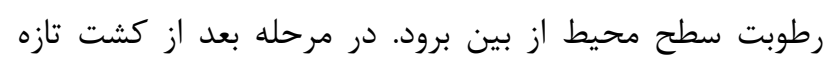

برخوردار است و در مناطق كَنجوان به هلاله، تنَتبينا، بين ميش خاص و كلم، بين كلم و بدره، دينار كوه، صالح آباد، ريكا و كردنا

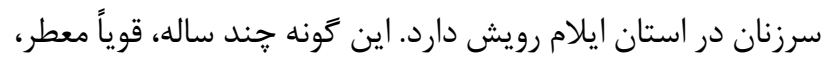

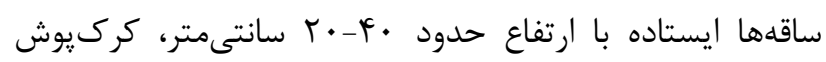

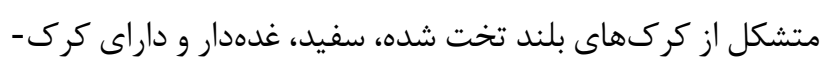

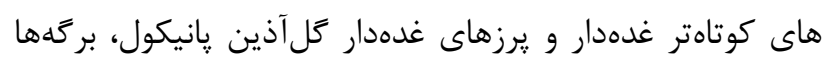

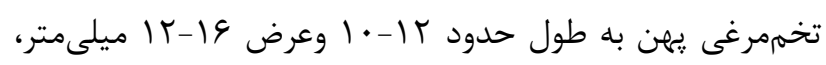
فندقه كم و بيش كروى و خاكسترى با ركههاى سياه است طرو

(Mozaffarian, 2008)

كونه Salvia bracteata كياهى جند ساله با قاعده كم و بيش

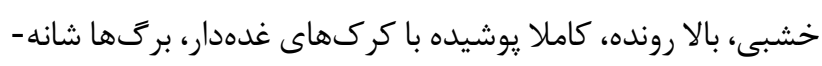

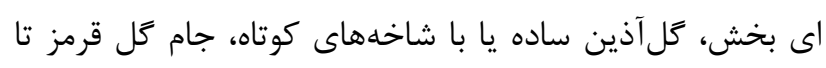

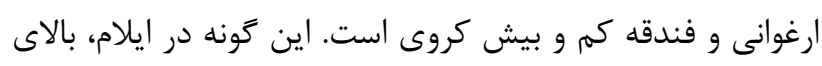
تونل رنو، كردنه قلاجه، كوه قلعه اسماعيل خان، تنخ دئ دالاب، ميمه،

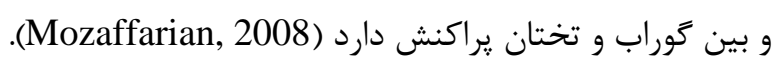
روش بررسى

كونهاى مريمَّلى در تحقيق حاضر از استان ايلام در بهار

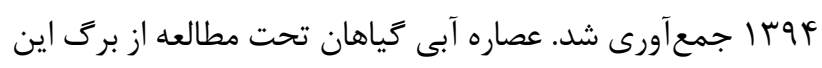

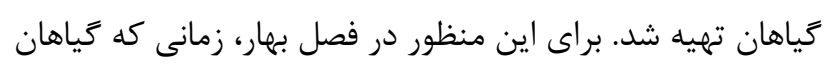

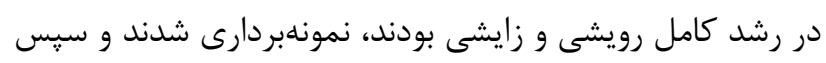

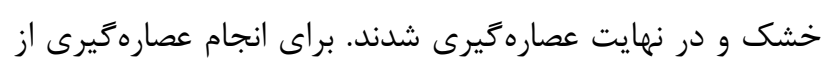

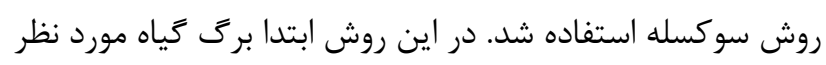

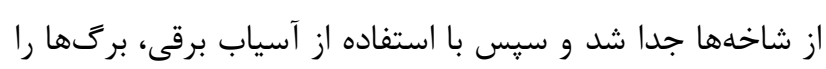

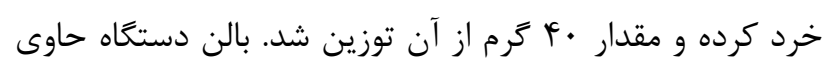

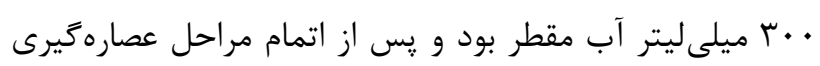

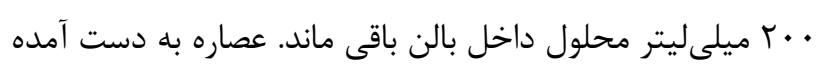

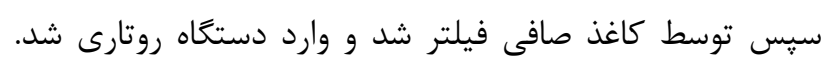

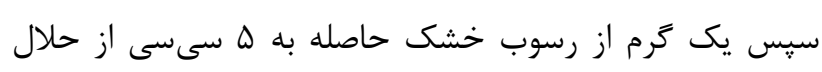

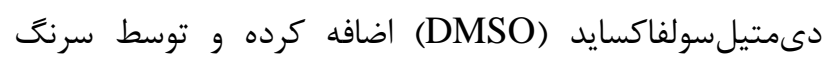

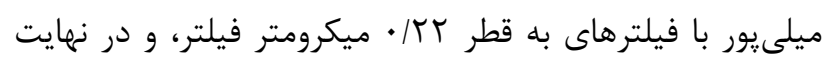

غلظتهاى مورد نظر تهيه شد (Haghighati et al., 2003). تهيه سويه هاى باكتريايى

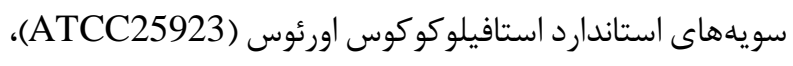

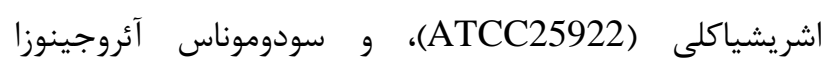
(ATCC27853) از آزمايشكاه ميكروبشناسى دانشكده يزشكى (ATCC25)

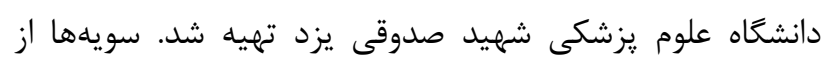

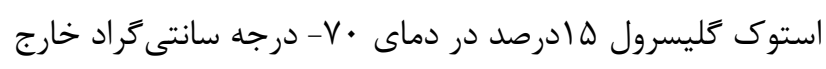
و در محيط كشت ترييتيكازسوىبراث ) Merck, Darmstadt, تلقيح شده و با كرمخانه كذارى در دماى (Germany

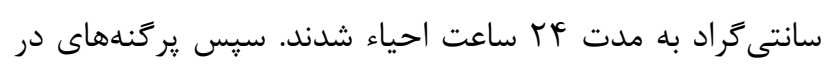


نتايج حاصل از عصاره Serspolitana در تست MIC روى

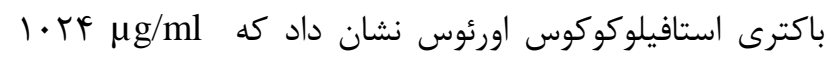

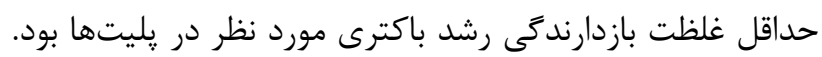

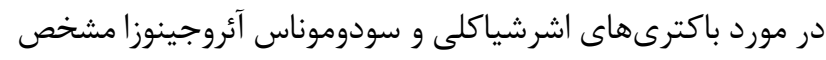

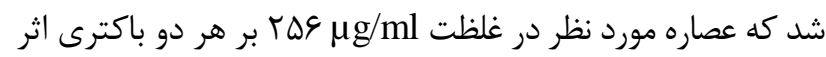

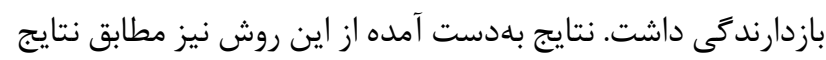

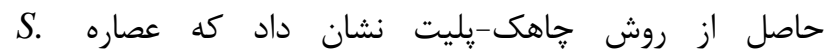
perspolitana

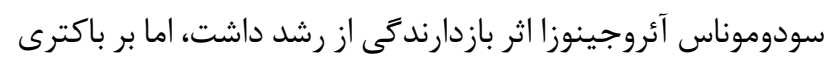

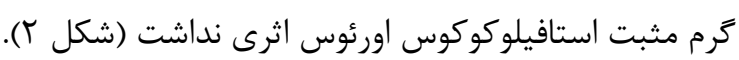

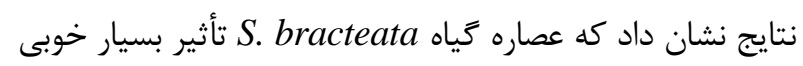
در جهت جلوكيرى از رشد باكترىهاى تحت بررسى داشت. در مورد

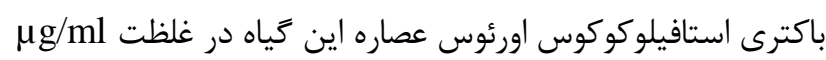

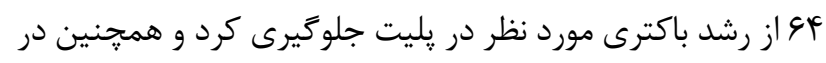

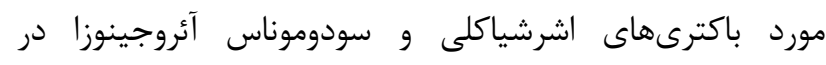

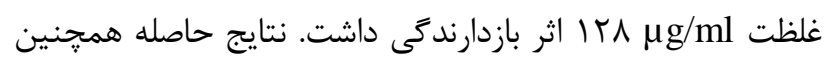

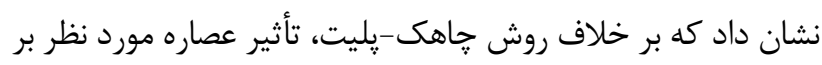

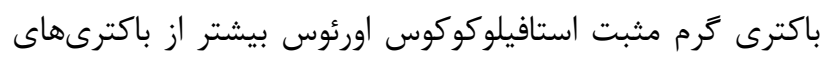

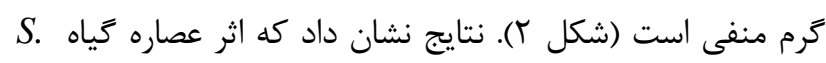
palaestina

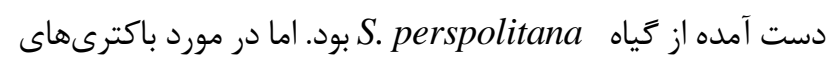

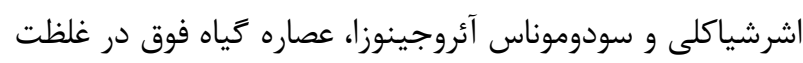

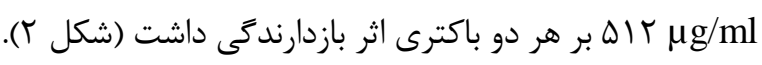

$$
\text { بحث و نتيجه كيرى }
$$

نتايج تحقيق نشان داد كه هاله عدم رشد در باكتئرى

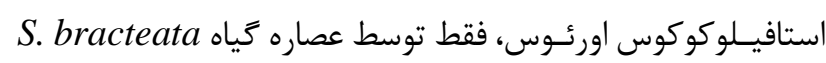

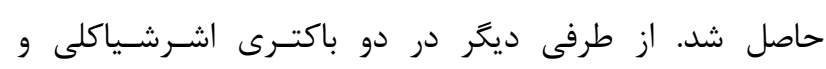

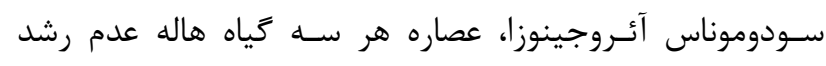

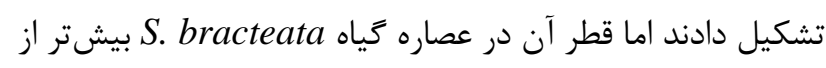
دو كَياه ديسكر بوده است.

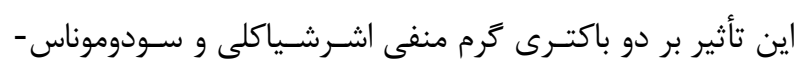

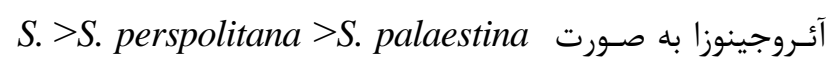
bracteata بود. مطالعات متعددى نشان مى دهد كه تركيبات مؤثره

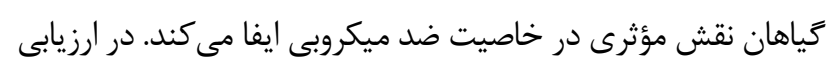

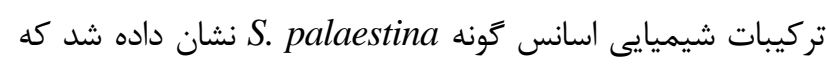

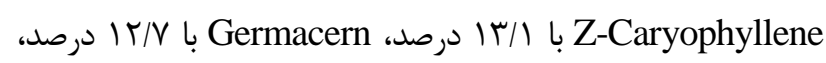
تركيات Tihydrocareol

تركيبات اين كونه را تشكيل مىدهد (Fattahi et al., 2014).
باكترى، سوسيانسيونى با كدورت لوله ف/ • مكفارلند تهيه شده با

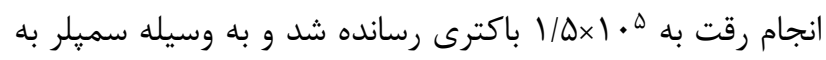

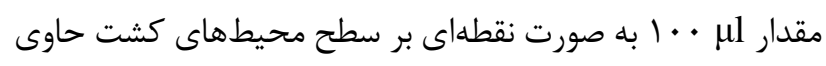

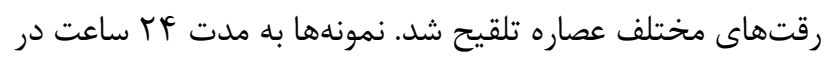

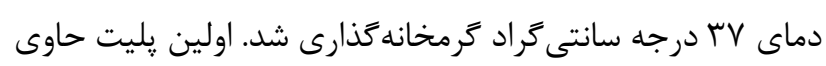

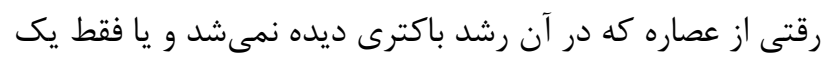
يا دو يركنه از باكترى وجود داشت به عند عنوان جهت كنترل منفى از يليت محيط مولرهينتون آكار حاوى باكترى

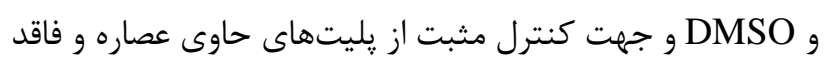

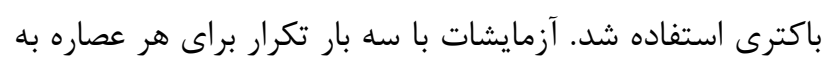

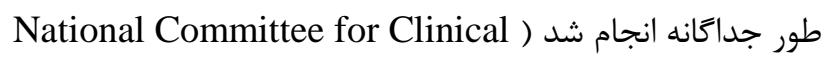
(Laboratory Standard 1990

\section{نتايج}

\section{بررسى يافتههاى حاصل از آزمون خاهك-يقيليت}

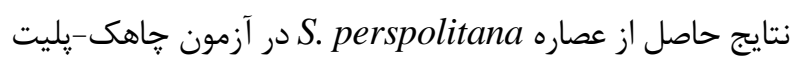

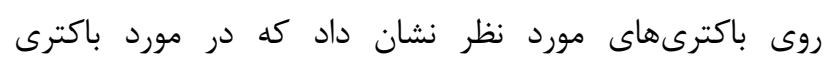

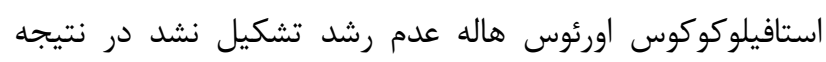

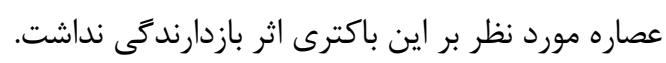

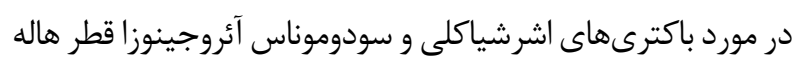

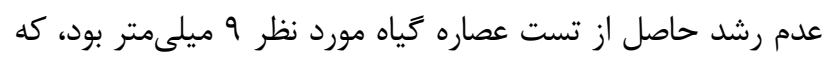

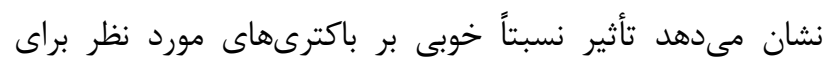

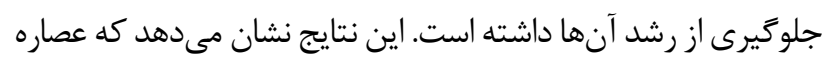

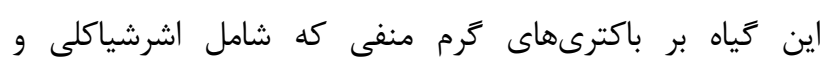

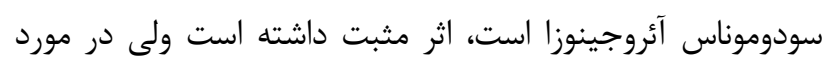

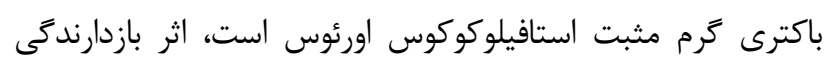

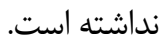
نتايج حاصل از عصاره S. bracteata نشان داد كه قطر هاله عدم رشد در مورد باكترى استافيلوكوكوس اورئوس 9 ميلى إمتره بود و در مورد باكترىهاى اشرشياكلى و سودوموناس آئروجينوزا

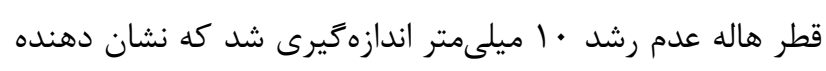

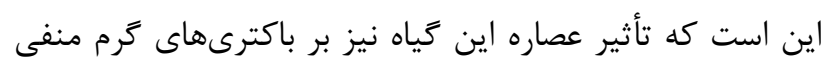
بيشتر از باكترى كرم مثبت است (شكل إن ().

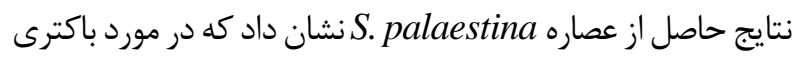

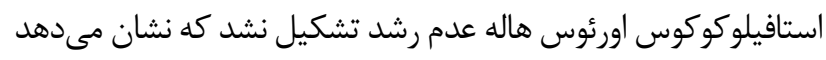

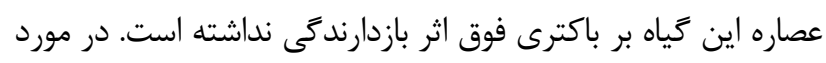

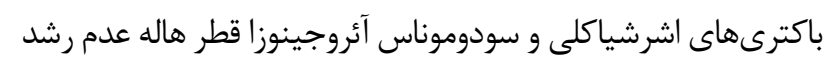

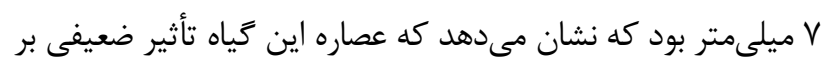
دو باكترى فوق داشته است (جدول ().

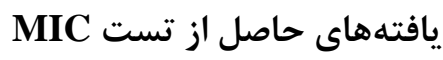



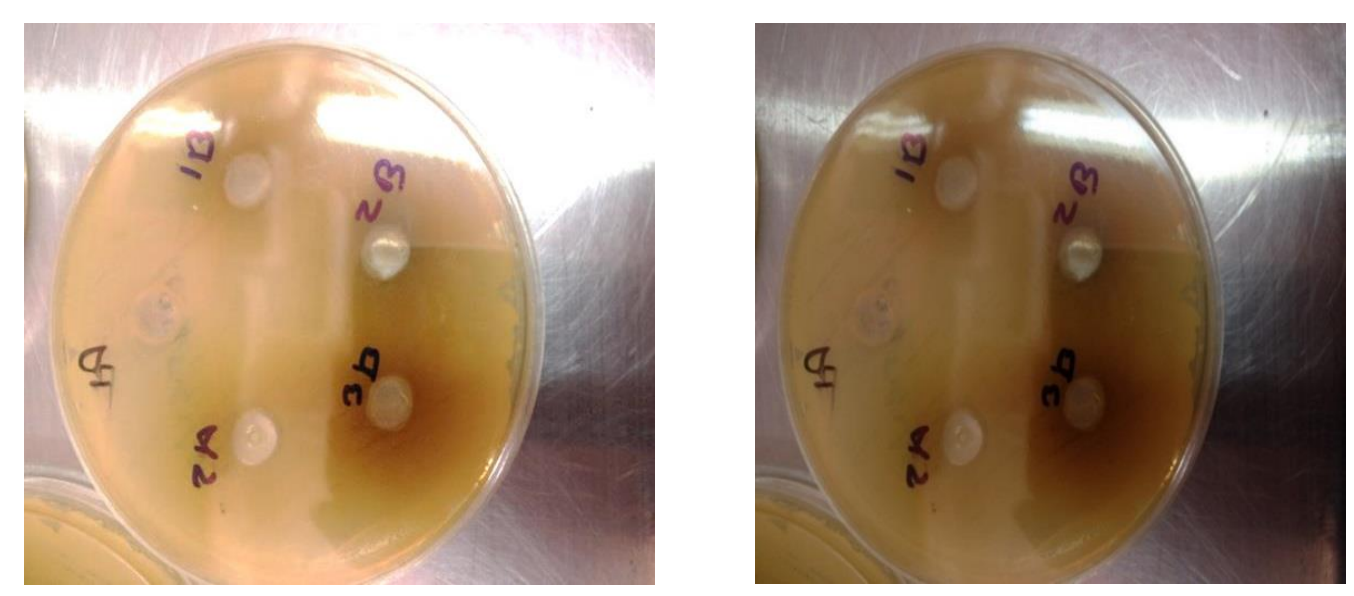

شكل ا- قطر هاله عدم رشد حاصل از تست عصاره كياهان مطالعه شده.

Fig. 1. Growth inhibitory zone resulted from water extracts of the studied plants.

جدول ا- قطر هاله عدم رشد حاصل از تست عصاره خياهان مورد نظر.

Table 1. Growth inhibitory zone resulted from the water extracts from the studied plants.

\begin{tabular}{|c|c|c|c|}
\hline كياه & استافيلوكوكوس اورئوس & اشرشياكولى & سودوموناسآئروجينوزا \\
\hline Salvia perspolitana & - & 9 & 9 \\
\hline S. bracteata & 9 & 1 . & 1. \\
\hline S. palaestina & - & v & v \\
\hline
\end{tabular}

ق\% واحد اندازميرى قطر هاله عدمرشد ميلىمتر است.

** The measurement for growth inhibitory zone is $\mathrm{mm}$.

شكل r- حداقل غلظت بازدارندگى عصاره آبى سه گونه مريم كلى بر سه باكترى تحت مطالعه.

Fig. 2. Minimum inhibitory concentration of the water extracts of the Salvia species on the studied bacteria.

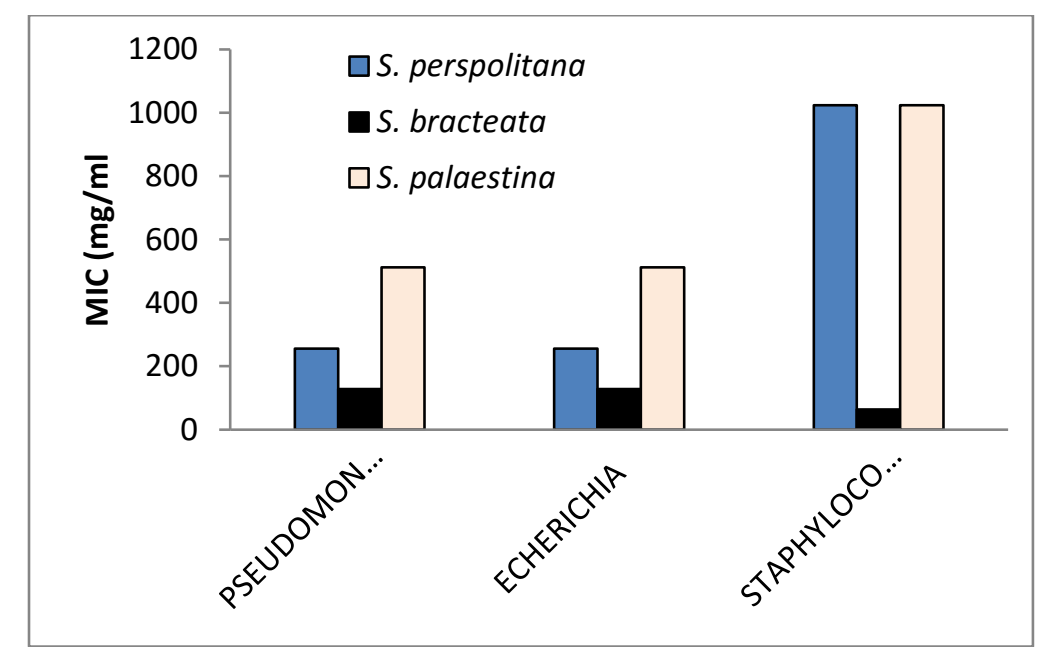

تشكيل مى دهند (Cursoy et al., 2012). اختلاف مشاهده شده در مورد تركيبات شيميايى و فعاليت ضد ميكروبى اسانسها در

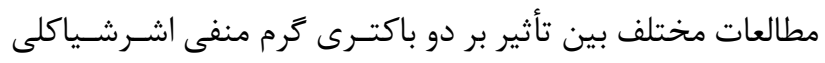

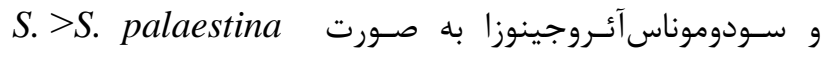
S. bracteata >perspolitana
مطالعات مشابه بر روى تركيبات شيميايى اسانس اين ₹ونه نتايج

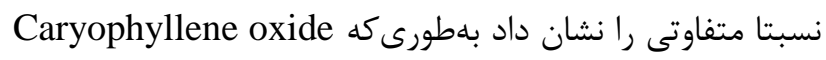

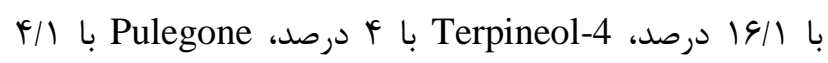

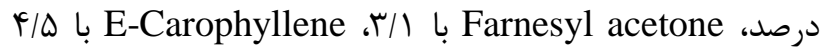
درصد و د-Copaene با ب درصد مهمترين تركيبات اين زونه را 
ميتوكندرى باكترىها مىشود و باعث ايجاد اختلال در عملكرد

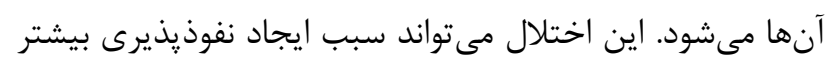

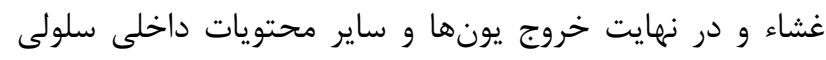

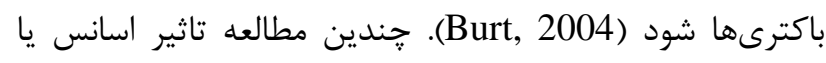

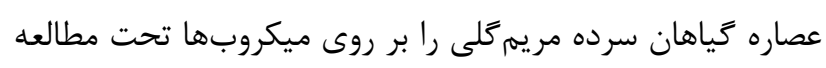

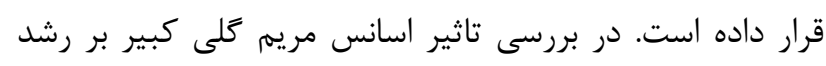

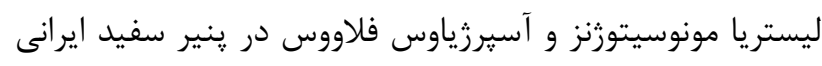

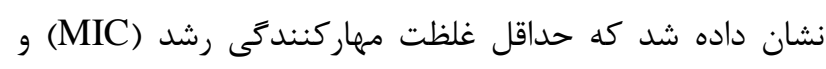
حداقل غلظت باكترى كشى (MBC) اسانس مريمكلى بلى بلهترتيب

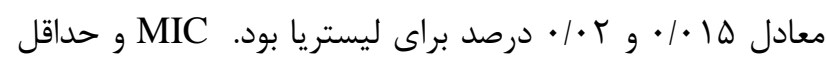

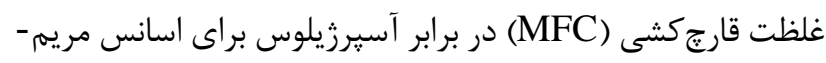

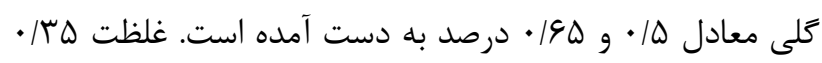

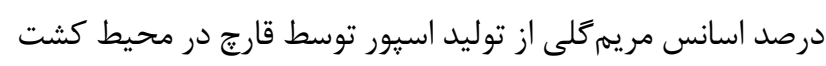

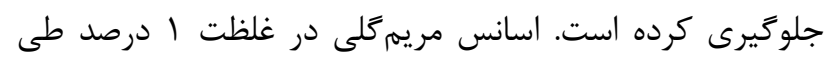

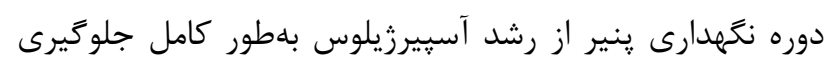

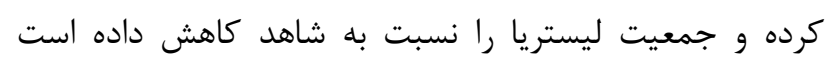

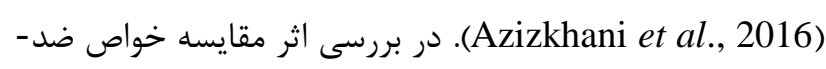

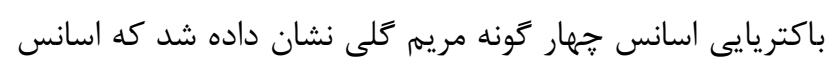

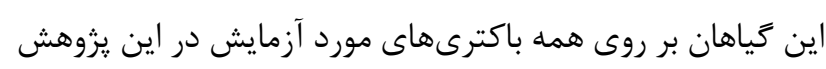

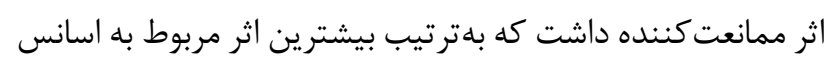

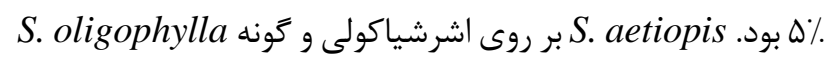

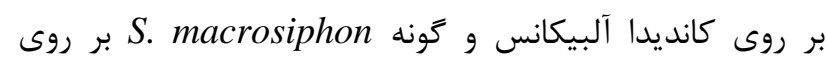

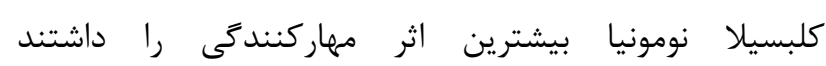

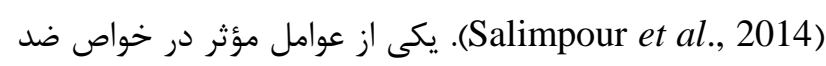

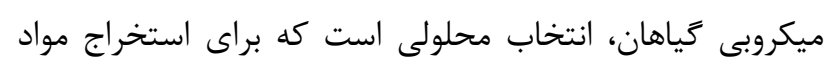

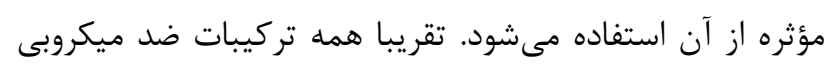

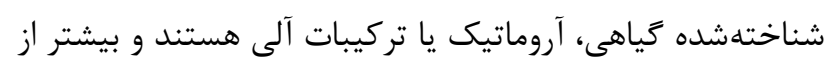

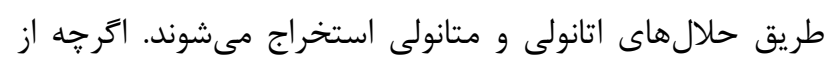

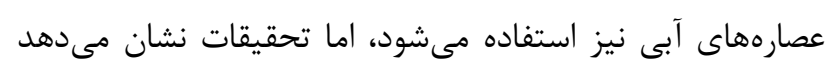

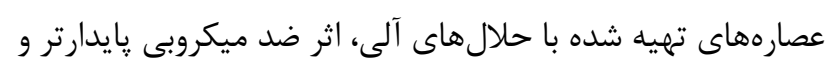

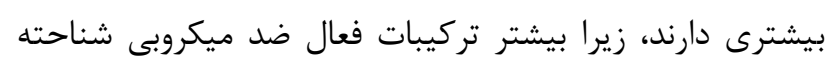

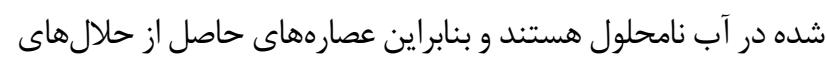
آلى براى استخراج تركيبات ضد ميكروبى توانمندى بيشترى دارئن (Giner et al., 2000; Safavi et al., 2013) تاثير كم عصاره آبى برخى از گونههاى سالويا تحت مطالعه ممكن :

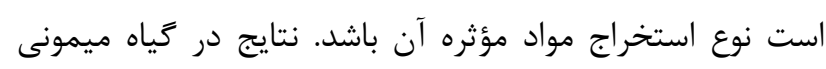

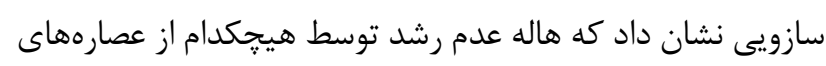

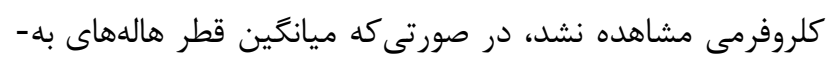

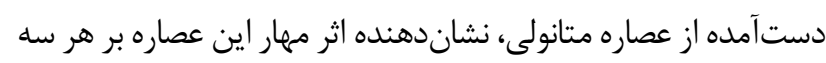
باكترى تحت مطالعه بود (Sharafati-Chaleshtori et al., 2010).
مطالعات متعددى نشان مى دهد كه تر كيبات مؤثره كياهان نقش

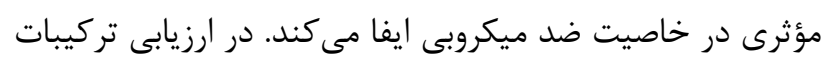

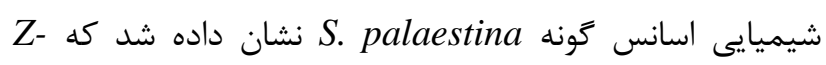
Caryophyllene Dihydrocareol

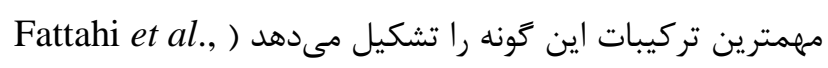

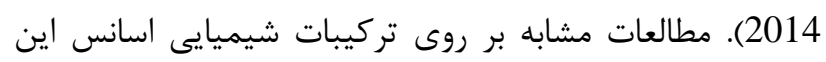

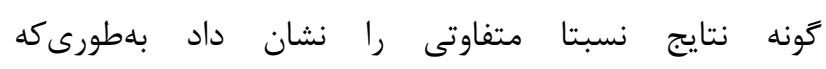
Caryophyllene oxide

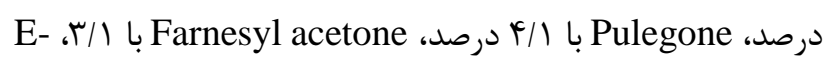
با Carophyllene

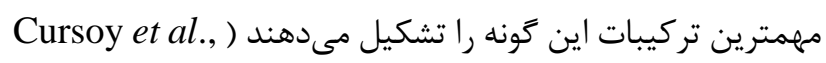

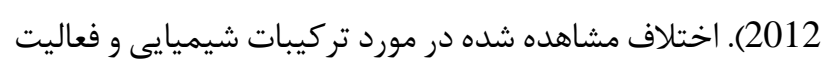

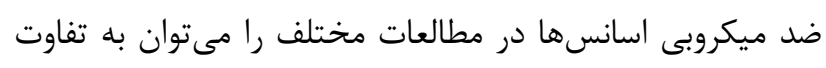

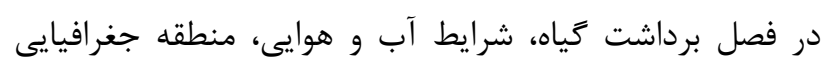

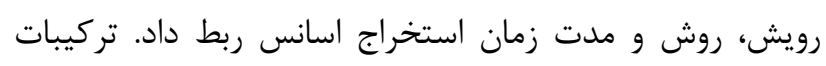
اسانس گونه ديخر تحت مطالعه در اين تحقيق،

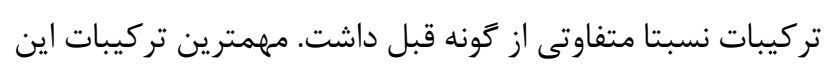

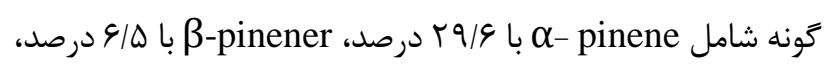

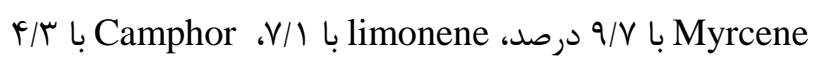

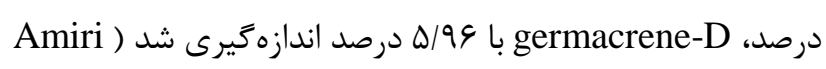
(et al., 2006 ). خاصيت ضد ميكروبى گونه S. officinalis 1.8-cineole, دهه قبل شناخته شد و اثر آن به تركيبات

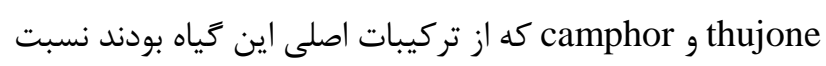
داده شد. به همين ترتيب ممكن است اثر ضد ميكروبى نسبتا مؤثر إنر

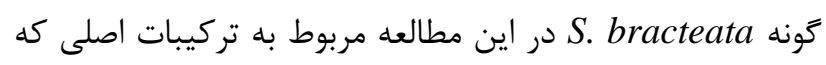

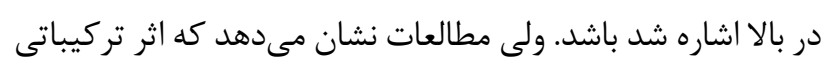

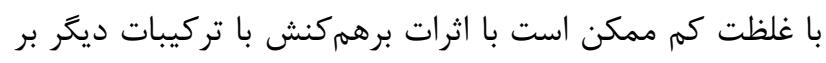

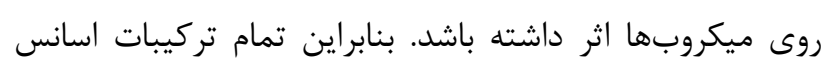
مى مواند در خاصيت ضد ميكروبى آن مؤثر باشد (Burt, 2004).

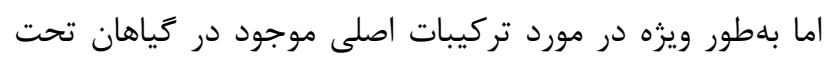

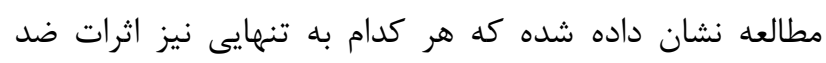

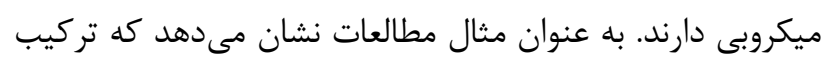
Azaz et al., 2002) Caryophyllene Magiatis et al., 2002) Caryophyllene oxide Q م موجود در سرده كياه Salvia sp.

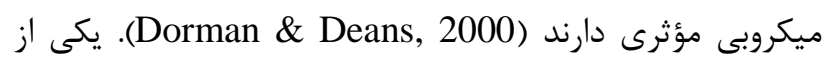
مهمترين دلايل اثر ضدميكروبى اسانس هاى كياهى وارنى وجود خاصيت

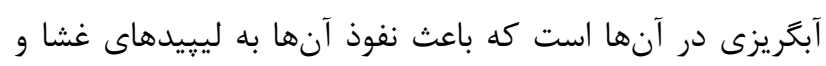




\section{REFERENCES}

Abbasi, N., Azizi Jalilian, F., Abdi, M. and Saifmanesh, M.A. 2007. Comparative study of the antimicrobial effect of Scrophularia striata Boiss: extract and selective antibiotics against Staphylococcus aureus and Pesudomonas aeroginosa. - J. Med. Plants 1: 10-18.

Amiri, H., Meshkat, A.l., Sadat, M.H., Lari Yazdi, H. and Goodarzi, A. 2006. Essential oil composition of Salvia reuterana Boiss. - Iran. J. Medl. Arom. Plants 22: 270275.

Azaz, D., Demirci, F., Satil, F., Kurkcuoglu, M. and Baser. K.H.C. 2002. Antimicrobial activity of some Satureja essential oils. - Nature 57: 817-821.

Azizkhani, M., Tooryan, F. and Boreiri, M. 2016. Effects of Ocimum basilicum and Salvia sclarea essential oils on Listeria monocytogenes and Aspergillus flavus in Iranian white cheese. - Iranian Food Sci. Technol. Res. J. 12: 286-295.

Burt, S. 2004. Essential oils: Their antibacterial properties and potential applications in foods. - Int. Food Microbiol. 94: 223-25.

Clauditz, A., Rescch, A., Wieland. K.P., Peschel, A. and Gotz, F. 2006. Staphyloxanthin plays a role in the fitness of Staphylococcus aureus and its ability to cope with oxidative stress. - Infect. Immun. 74: 4950-4953.

Cursoy, N., Tape, B. and Akpulat, H.A. 2012. Chemical composition and antioxidant activity of the essential oils of Salvia palaestina and S. ceratophylla. - Rec. Nat. Prod. 6: 278-287.

Dorman, H.J.D. and Deans, S.G. 2000. Antimicrobial agents from plants: antibacterial activity of plant volatile oils. - J. Appl. Microbiol. 88: 308-316.

Fattahi, B., Nazeri, V., Kalantari, S. and Bonfill, M. 2014. Identification of compounds in the essential oil and quantification of flavonoids and rosmarinic acid in Salvia reuterana and Salvia palaestina Benth. Iranian J. Medl. Arom. Pants 30: 463-475.

Formisano, C., Senatore, F., Arnold, N.A., Piozzi, F. and Rosselli, S. 2007. GC and GC/MS analysis of the essential oil of Salvia hierosolymitana growing wild in Lebanon. - Nat. Prod. Com. 2: 181-184.

Giner, R.M., Villalba, M.L., Recio, M.C., Mañez, S., Cerdá Nicolás, M. and Ríos, J.L. 2000. Antiinflammatory glycoterpenoids from Scrophularia auriculata. - Eur. J. Pharmacol. 389: 243-52.

Haghighati, F., Jafari, S. and Momen Beitollahi, J. 2003. Comparison of antimicrobial effects of ten herbal extracts with chlorhexidine on three different oral pathogens; an in vitro study. - Hakim Med. J. 6: 6-71.

Hedge, I.C. 1982. Salvia L. - In: Rechinger, K.H. (ed.), Flora Iranica 150: 403-476. Akademische Druck und Verlagsanstalt, Graz.

Inouya, S., Takizawa, T. and Yamaguchi, H. 2001. Antibacterial activity of essential oils and their major constituents against respiratory tract pathogens by gaseous contact. - J. Antimicrobial Chem. 47: 565-573.

Kluytmans, J., Van Belkum, A. and Verbrugh, H. 1997. Nasal carriage of Staphylococcus aureus: epidemiology, underlying mechanisms, and associated risks. - J. Clin. Micrbiol. 3: 505-520.
در آزمايش حاضر اثر عصاره گياهان تحت مطالعه بيشتر بر باكترىهاى گرم منفى مشاهده شد. مشابه اين نتايج نشان داده شده است كه خواص ضد ميكروبى زياهان بر باكترىهاى گرم منفى بيشتر است، مكر آنكه از غلظتهاى بالاترى استفاده شود ( Kluytmans .(et al., 1997; Safavi et al., 2013

$$
\text { نتيجه تيرى }
$$

نتايج نشان داد كه فقط عصاره S. bracteata در پريليت Staphylococcus aureus Escherichia coli, ) عصاره هر سه گياه بر روى دو باكترى ديگر (Pseudomonas aeruginosa مجددا تاثير عصاره S. bracteata بيشتر بود. نتايج در آزمايش

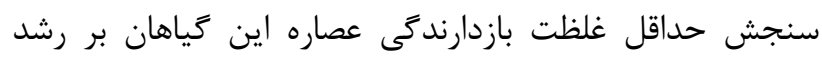
باكترىها نيز نشان داد كه عصاره گياه S. bracteata در غلظتهاى يايين نيز باعث عدم رشد باكترىهاى مورد مطالعه شد در حاليكه حداقل غلظت بازدارندگى رشد باكترى در دو زئياه ديكر

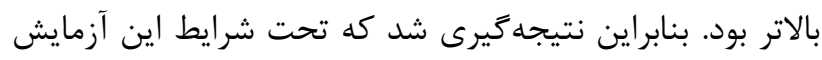

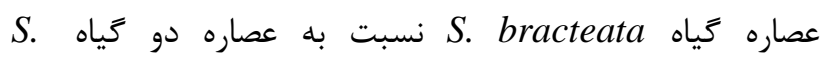
S. palaestina perspolitana دارد و مىتواند بهعنوان ماده ضد ميكروبى مورد توجه قرار گيرد.

$$
\begin{aligned}
& \text { سباسگزןارى } \\
& \text { بدينوسيله از زحمات كارشناسان آزمايشگاه دانشگاه علوم } \\
& \text { يزشكى شهيد صدوقى يزد كه نويسند } \\
& \text { يارى كردند، قدردانى مىشود. }
\end{aligned}
$$


Magiatis, P., Skaltsounis, A., Chinou, I. and Haroutounian, S.A. 2002. Chemical composition and invitro antimicrobial activity of the essential oil of three Greek Achillea species. - Nature 57: 287-290.

Mozaffarian V. 2008. Flora of Ilam. Farhang Moaser Publication, Tehran. 671pp.

Mozaffarian V. 1996. Dictionary of Iranian plant names. Farhang Moaser Publication, Tehran. 700pp.

National Committee for Clinical Laboratory Standard. 1990. Methods for dilution antimicrobial susceptibility tests for bacteria that grow aerobically. - Approved Standard Order M7-A2: 1-31.

Pirnia, M., Edalatian Dovom, M.R., Tabatabaee Yazdi, F., and Shahidi, F. 2014. The antibacterial effects of the Aqueous and Ethanolic extracts of Cordia myxa fruit on Staphylococcus aureus, Bacillus cereus, Escherichia coli and Salmonella typhi. - Qom Univ. Medl. Sci. J. 9: 39-48.
Safavi, F., Ebrahimi, P. and Mighani, H. 2013. In vitro anti-bacterial activity of root and aerial parts of Scrophularia striata on Escherichia coli, Staphylococcus aureus and Bacillus cereus. - YUMSJ 18: 603-614.

Salimpour, F., Moazooji, A., Mazhar, F. and Barzin, G. 2014. Comparative study of antibacterial properties of four species of Salvia L. as a medicinal plant. - J. Res. Medl. Sci. 37: 205-210.

Sharafati-chaleshtori, R., Sharafati-chaleshtori, F., Sharafati-chaleshtori, A. and Ashrafi, K. 2010. Antimicrobial effects and evaluation of total phenols, flavonoids and flavonols contents of ethanolic extracts of Scrophularia striata. - J. Shahrekord Univ. Medl. Sci. 11: 32-37.

Walker, J.B. and Sytsma, K.J. 2007. Stamina evolution in the genus Salvia molecular phylogenetic evidence for multiple origins of the lever. - Ann. Bot. 100: 375-391.

How to cite this article:

Mosleh Arany, A., Nemati, N., Zandi, H. and Naderi, M. 2020. Antibacterial activity of water extracts of three species of Salvia on Staphylococcus aureas, Escherichia coli and Pseudomonas aeruginosa. - Nova Biologica Rep. 6: 446-453. (In Persian)

$$
\begin{aligned}
& \text { مصلح آرانى، ا.، نعمتى، ن.، زندى، ه. و نادرى، م. 1وب ا. بررسى اثر ضد ميكروبى عصاره آبى سه كونه مريمكلى بر باكترىهاى استافيلوكوكوس اورئوس، اشرشيا }
\end{aligned}
$$

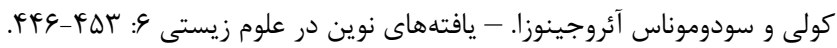

